\title{
SEISMIC INVESTIGATIONS OF GLACIAL STRUCTURES IN NORTHERN GERMANY
}

\author{
Helga Wiederhold" \& Gerfried Caspers ${ }^{2)}$ \\ 1)NLfB-GGA, Stilleweg 2, D-30655 Hannover \\ ${ }^{2)} \mathrm{NLfB}$, Stilleweg 2, D-30655 Hannover
}

Shallow subsurface structures in Northern Germany and adjacent areas are characterized by glacial erosion and deposition. Thus, a system of up to $400 \mathrm{~m}$ deep channels mainly formed during the glaciation of the Elster period and filled with sediments afterwards is known and today of special interest for hydrological questions. Other glacial depressions, especially hollows with no outlet, are excellent sediment traps and afford optimum conditions for the study of stadial and interstadial deposits and thus, the reconstruction of climate and vegetation development during glacial epochs.

Such a hollow filled with eemian and weichselian sediments is found near Hamburg (Germany) and was target of a research project in 1993/1994 conceming Weichselian Interstadials (Caspers 1997). By drilling and probing detailed knowledge is gained up to the bottom of the structure at a depth of about $60 \mathrm{~m}$. With a maximum width of $200 \mathrm{~m}$ the structure is very steep. Extensive stratigraphical, palynological and geochronological investigations were carried out on the organic sediments of five interstadials.

For a better understanding of the geological setting a high-resolution reflection seismic profile was shot in 1996. The seismic waves were generated by the impuls source system "SISSY". Reflections from $30 \mathrm{~m}$ up to $400 \mathrm{~m}$ depth are observed revealing a clear picture of the structure (Fig. 1). The lateral boundaries of the hollow (between $500 \mathrm{~m}$ and $700 \mathrm{~m}$ and down to $100 \mathrm{~ms}$ TWT) are too steep to be pictured as reflections but phase splitting and reflections of the sedimentary filling clearly mark the structure. The seismic section also clearly shows that the structure is underlain by another much wider and deeper depression (between $400 \mathrm{~m}$ and $780 \mathrm{~m}$ and down to $160 \mathrm{~ms}$ TWT). Presumably this belongs to the elsterian channel system.

Besides the structural investigation the seismic survey was a test for the seismic impuls system "Sissy“. Originally designed as supplement for a weight dropping system in unaccesible terrain (Buness et al. 1997a) this survey shows its usefulness for reflection seismic profiling. In June 1997 an additional line will be measured concentrating in field geometry and data acquisition parameters on the hollow itself. A newly developed high frequency vibroseis source with nominal frequencies up to $500 \mathrm{~Hz}$ promises really high resolution of the sedimentary filling (Buness et al. 1997b). 


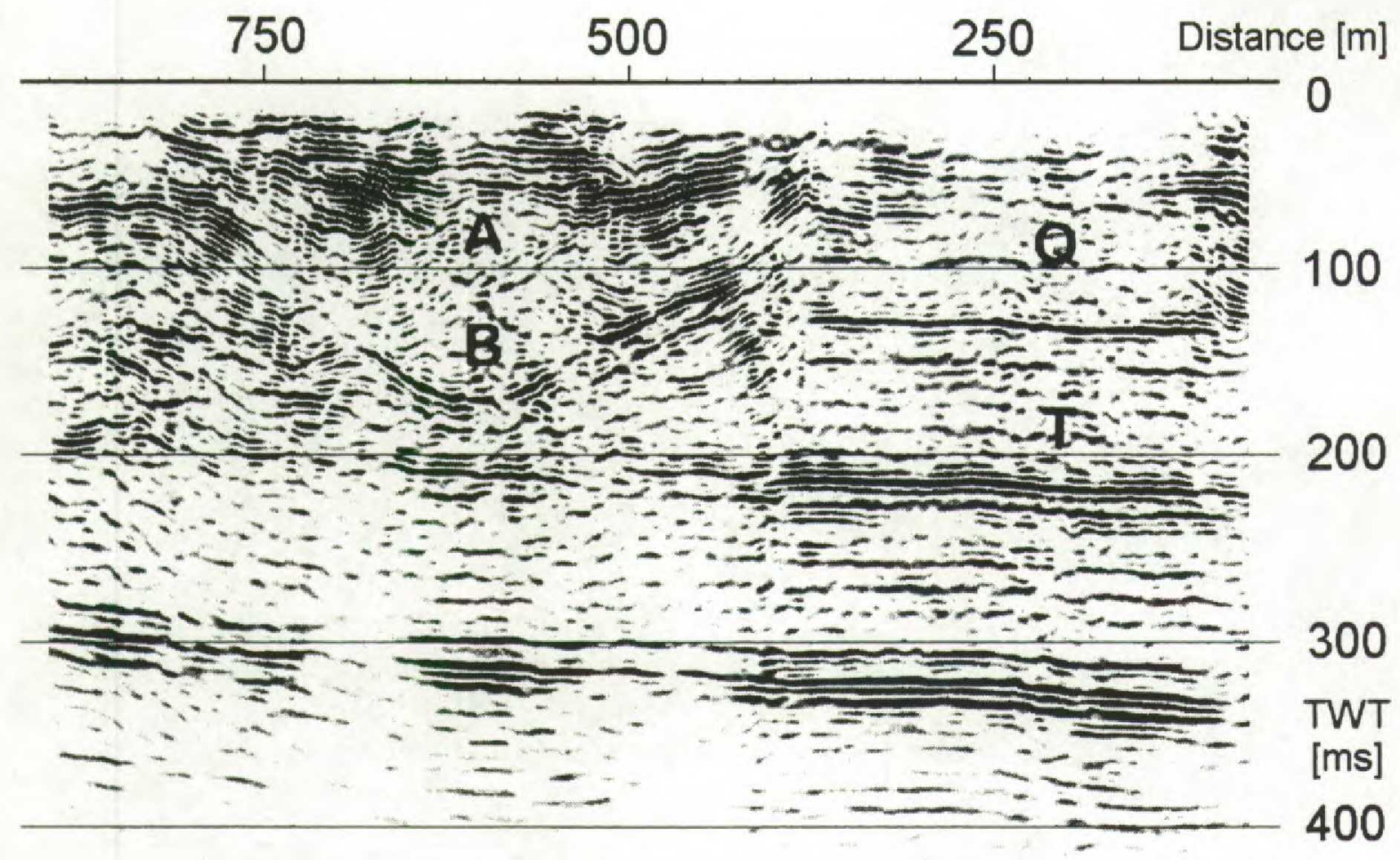

Fig. 1: High resolution seismic section (migrated).

$\mathrm{A}=$ hollow with eemian and weichselian deposits,

$\mathrm{B}=$ channel, presumably formed during Elsterian glaciation,

$\mathrm{Q}=$ Quarternary,

$\mathrm{T}=$ Tertiary.

Field parameters: Souce: „Sissy“, $100 \mathrm{~Hz}$ geophones, 48 channels, shot point distance $5 \mathrm{~m}$, receiver distance $5 \mathrm{~m}$, CMP distance $2.50 \mathrm{~m}$, bandpass filter $70-500 \mathrm{~Hz}$, sampling rate $0.5 \mathrm{~ms}$.

References:

Buness, H., Druivenga, G., and Wiederhold, H., 1997a. SISSY - eine tragbare und leistungsstarke seismische Energiequelle: Geol. Jahrbuch, E57, Hannover, in press.

Buness, H., Bram, K., Druivenga, G., and Grüneberg, S., 1997b. A vibrator system for shallow high-resolution reflection seismics. Extended Abstracts, 59th EAGE Conference and Technical Exhibition, Geneva.

Caspers, G. 1997. Die eem- und weichselzeitliche Hohlform von Groß Todtshorn (Kreis Harburg; Niedersachsen) - Geologische und palynologische Untersuchungen zu Vegetation und Klimaverlauf der letzten Kaltzeit. Schriftenreihe Deutsche Geologische Gesellschaft, 4, Hannover, in press. 